\title{
OPTIMIZATION OF WATER RESOURCES MANAGEMENT OF DEPOK CITY WITH WATER STRESS INDEX AND SWOT ANALYSIS
}

\author{
Firdaus Ali ${ }^{1,2,3 *}$, Dwi Lintang Lestari ${ }^{2}$, Marsya Dyasthi Putri ${ }^{2}$, Khalidah Nurul Azmi ${ }^{2}$ \\ ${ }^{1}$ Faculty of Engineering, Universitas Indonesia, Depok 16424, Indonesia \\ ${ }^{2}$ Indonesia Water Institute, South Jakarta 12530, Indonesia \\ ${ }^{3}$ Ministry of Public Works and Housing, Jl. Pattimura No. 20, South Jakarta 12110, Indonesia
}

(Received: June 2018 / Revised: August 2018 / Accepted: November 2018)

\begin{abstract}
Excessive groundwater use is one of an impact from excesses of population growth that can give impacts to environmental quality. Therefore, conversion to piped water needs to be carried out immediately. Depok City Government has to add water treatment plants (WTP) that will use the rivers that cross the city. The four rivers are Angke, Pesanggrahan, Ciliwung, and Cikeas River, which is the river infrastructure is not optimal. This research has several goals, namely analysis of the water needs, evaluation of the condition of the rivers, and provide recommendations to the stakeholder. Therefore, it can be seen that there is a combination of several methods to convert quantitative data into qualitative. This study uses the analysis method of water-stress indicators (WSI) and water balance calculations to determine the condition of water resources in the Depok area at this time. The results of the analysis show that there are two villages with very high WSI, namely Bojongsari and Cipayung. This is due to the absence of piped water lines in the two regions. Based on the results of the water balance analysis, it can be seen that the strategy in increasing the capacity of WTP has a significant impact until 2027, but there needs to be additional supply back in 2027 as an increase in water demand so that depletion in the water balance can be avoided. Based on the Strengths, Weaknesses, Opportunities, and Threats (SWOT) analysis, it is found that the management of water resources of Depok City is on quadrant IV. Thus, the strategy to be applied is an Adaptive Strategy, which reduces the weaknesses and avoids threats. Therefore, the management of water resources Depok City is recommended to control the internal performance from falling apart. This strategy is maintained while continuing to improve itself.
\end{abstract}

Keywords: Water resources; Water consumption; Water policy

\section{INTRODUCTION}

Indonesia with high population burden and geographical condition of the archipelagic country also face severe challenges related to global urban problems. The water crisis is in the form of a shortage to meet the needs of most of the time and the massive excess in the rainy season thus triggering an increased risk of disasters related to water and weather and climate.

In this case, focused on the city of Depok, where the city is a metropolitan area of urban suburbs of DKI Jakarta that accommodate the burden of the population increased from year to year.

*Corresponding author's email: firdausali@ymail.com, Tel. +62-81-513652121, Fax. +62-21-7814276 

With the increase of population, it will have an impact on the decrease of environmental and spatial support capacity, the emergence of accessibility and traffic burden problems, water governance and damage control and water damage, and solid waste management and environmental sanitation.

Depok City Government has launched the development of several water treatment plants (WTP) for distributed through piped water network (Regional Regulation of Depok City No. 1 of 2015 on Depok City Spatial Plan 2012-2032). Development of the WTP will use the rivers that cross the city of Depok as a source of raw water. The rivers are Angke River, Pesanggrahan River, Ciliwung River, and Cikeas River. The condition of the four rivers has not been able to meet the infrastructure requirements for the provision of raw water. Through this research, it is expected to achieve several goals: (1) Conducting an analysis of the water needs of the city of Depok; (2) Conducting analysis and evaluation of the condition of the four rivers that will be used as raw water source of WTP; and (3) Provide policy recommendations to the parties that related to efforts to meet water needs.

The study was conducted by analyzing the need for clean water, and the availability of raw water sources by including analysis of river conditions, year-round water availability, flow continuity, and river water quality, and watershed land use analysis. This study uses adjustments in the selection of water-stress indicators so that the results of the research can be focused on water resources infrastructure and government policies to overcome the problem of water supply provision.

\section{LITERATURE STUDY}

Water stress is defined by the World Water Assessment Program (Molle \& Mollinga, 2003), by looking at it as a condition of water that has sufficient quality and quantity that is satisfactory to meet human and environmental needs (Molle \& Mollinga, 2003). The meaning of the word is enough here to match the existing needs. The idea of WSI was raised by Sullivan (2005) who discussed background theoretically (Sullivan et al., 2005). WSI is created with the participation of various consultants, stakeholders, decision-makers, and scientists. The result of this discussion is the emergence of five index components. This process provides an assessment of life assets (Mlote et al., 2002). Five components are considered in the calculation of WSI namely resources, access, capacity, use, and environment (Sullivan et al., 2005). Effective WSI implementation will facilitate the government to monitor progress at any time. The first measurement of WSI at the location will be the basis, and changes at any time will be proven by recalculation at more specific intervals.

A SWOT analysis is an instrument used in strategic planning by looking at the analysis of internal and external conditions. The qualitative and quantitative approaches of the SWOT matrix were developed by Kearns by analyzing external factors (Opportunities and Challenges) and internal factors (Strengths and Weaknesses). From this analysis, a strategic solution will emerge that can be given to solve existing issues.

\section{METHODS}

\subsection{Variable Research}

The variables used in this study are divided into dependent variables and independent variables. In this study, the independent variables are any components that affect the concept of water governance, while the dependent variable is the water balance and policy mapping. The independent variable used in this research is the indicator of water stress (WSI). WSI functions as a systematic and transparent tool that can provide information form of water resources conditions (Molle \& Mollinga, 2003). Thus, WSI provides convenience in determining priority 
issues. The results of WSI can be expressed very simply, namely a single numbering form that can be used to represent a location. Effective WSI implementation will provide convenience government to monitor progress at any time (Sullivan et al., 2003). In this research, the indicator of WSI that used consist of water availability, water consumption level, water source continuity, water source quality, and land use.

\subsection{Sample and Population}

Population and sample in each sub-district use secondary data. To know the number of people who do not use PAM can be done by reducing the population recorded in Depok residence statistics with the number of residents who are PAM customers. The following is the population in the study area:

- Population of Depok $=2,106,100$ persons or 515,441 families (Depok in Numbers, 2016)

- The number of residents (PDAM customers) $=$ 52,255 families (PDAM Kota Depok, 2015)

- The number of residents who are non-PDAM customers $=463,186$ families.

Sampling technique to be used is probability sampling. Calculation of the required number of samples can be done by Slovin method, Equation 1:

$$
n=\frac{N}{1+N e^{2}}
$$

Where: $\mathrm{n}=$ number of samples; $\mathrm{N}=$ population number; $\mathrm{e}=$ limit tolerance of error (error tolerance). Research with a 5\% error limit has a 95\% accuracy rate. With the provisions set forth above, it can be calculated the size of the sample for the survey questionnaire as follows:

- Samples of PDAM customers $=397$

- Samples of non-PDAM customers $=400$

By knowing the required number of samples, then the distribution of questionnaires to each district can be conduct. In this research, data processing will be done by performing an indicator analysis affecting water supply in a region, then continued with water balance calculation and SWOT analysis to determine the direction of standard water supply policy.

\subsection{Water Supply Indicator Analysis}

In this study, each indicator value has a maximum value of 20 and will be given scaling with a weighted value (Lestari, 2011). Weight values are searched by Thurstone method. The step of this method is to provide a quantitative scale on each indicator that describes the level of water supply at the study site. After the weight value of each respondent (expert team) is obtained, then averaged. The average value of this weight represents the amount of water supply in Depok for each indicator. So that we can generate the final weight and map value, which is the result of this research.

\subsubsection{Water Availability Indicator}

To calculate water availability in a sub-district, Equation 2 is used:

$$
K A=\frac{A T+A P+P A M}{P}
$$

Where: $\mathrm{KA}=$ water availability $\left(\mathrm{m}^{3} /\right.$ year/person $) ; \mathrm{AT}=$ groundwater debit $\left(\mathrm{m}^{3} /\right.$ year $) ; \mathrm{AP}=$ surface water debit $\left(\mathrm{m}^{3} /\right.$ year $) ; \mathrm{PAM}=$ piped water debit $/ \mathrm{PAM}\left(\mathrm{m}^{3} /\right.$ year $) ; \mathrm{P}=$ number of population (person). This calculation is based on the Falkenmark indicator.

\subsubsection{Water Continuity Indicator}

Continuity is reviewed by flowing water over 12 hours or drainage of fewer than 12 hours. Determination of scores for continuity of drainage of each source of clean water is taken from the middle value of 10 and the maximum value of 20 . After that, we can calculate the value of water source continuity indicator with Equation 3: 
Where: $\% \mathrm{NPAM}=$ Percentage of the population not subscribed to PAM; KAT = Continuity scores on groundwater sources; CAS = Continuity scores on river water sources; \% $\mathrm{PAM}=$ Percentage of people who subscribe to PAM; KPAM = Continuity scores on piped water sources/PAM.

\subsubsection{Water Quality Indicator}

The quality of the monitored water resource is groundwater, surface water, and piped water. Surface water quality parameters monitored are physical, chemical, and microbiological parameters referring to Government Regulation No. 82/2001 on the management of Water Quality and Water Contamination Control of the President of the Republic of Indonesia. The parameters are calculated using pollutant index to obtain groundwater quality status by Appendix II of Ministry of Environment Decree No.155/2003 on "Use of Environment Index on Water Pollution". Assessment of PAM water quality on this indicator is based on the complaints of costumer that have the parameters of odor, taste, and clarity of the water. From all of the water quality assessments, the average score will be calculated for inclusion into the weighting.

\subsubsection{Water Consumption Indicator}

The level of clean water consumption is divided into two, namely the level of water consumption of piped water customers and not piped water customers. The calculation of the value of clean water with weighting can be seen in Equation 4:

$$
A=\frac{(P \times A 1)+(N p \times A 2)}{P+N p}
$$

Where: $\mathrm{A}=$ Level of clean water consumption in district area $(1 /$ person $/ \mathrm{h}) ; \mathrm{P}=$ Number of piped water customers (people), $\mathrm{Np}=$ Amount not piped water customers (people); $\mathrm{A} 1=$ Customer's net water consumption level $(1 /$ person $/ \mathrm{h}) ; \mathrm{A} 2=$ Level of non-customer water consumption $(1 /$ person/h).

\subsubsection{Land Use Indicator}

Before the calculation of the indicator value, the first score based on the type of land allotment is determined. Each score is determined based on the impact of water use and water pollution on the ecosystem. Allotment of land to be used is a settlement, public facility, industry, and open land. In this study, the weighted value to be set has a range between 0 and 1 . The water supply level approaching 1 illustrates the area already has a good water supply, otherwise if the WSI value near 0 indicates that the region does not have a sufficiently good water supply. The value of such weights can be obtained with Equation 5:

$$
\frac{20-\frac{\sum_{1}^{i} I_{i} \cdot W_{i}}{W_{t}}}{20}
$$

Where: $\mathrm{Ii}=$ Value of the $\mathrm{i}$-th indicator; $\mathrm{Wi}=$ The weight of the $\mathrm{i}$-th indicator; $\mathrm{Wt}=$ Total weighting. By knowing the weight value of each sub-district, the water-prone level of the area under study can be known. In this study, the classification of the water supply level is divided into five levels, where the water supply level constraint is 0.4 . The five water supply classification levels are as follows:

- Very Low Water Supply Area: Indicator weight $>0.5$

- Bad Water Supply Area: $0.4<$ Indicator weight $\leq 0.5$

- Medium Water Supply Area: $0.3<$ Indicator weight $\leq 0.4$

- Good Water Supply Area: $0.2<$ Indicator Weight $\leq 0.3$ 
- Very Good Water Supply Area: Indicator Weight $\leq 0.2$

\subsection{Water Balance Analysis}

Water balance will be beneficial to ensure the sustainability of the carrying capacity and the environmental capacity of the area from the aspect of water availability. Data collection is done through literature study, primary data compilation and supporting data, review, and analysis of existing water balance components, surveys and field measurements or representative, followed by simulation models to obtain quality data. Analysis of calculation and projection of the number of water needs, would be determined by the total population to be served, the type of activity socioeconomic, the water requirements for activities supporting urban areas such as water for firefighting, watering plants and gardens, the water for the flushing channel city, and water for the needs of the port. Standard water requirements for various activities or urban facilities refer to SNI 03-7065-2005 concerning Planning Procedures for Plumbing. Meanwhile, water demand for firefighting is set at $20 \%$ of PDAM's reservoir capacity or $5 \%$ of domestic needs (Technical Guidelines for Clean Water Supply System for regional settlement and infrastructure, 1998). Meanwhile, for the analysis of water supply seen from the water resources in the area, in this case, the water supply is provided by the Depok City Regional Drinking Water Company Tirta Asasta. The results of this water balance arrangement are expected to give an idea of how the level of water security (water security) for 20 years into the future. The projection of population will be made by using projection data which has been issued by Depok City Central Bureau of Statistics.

\subsection{SWOT Analysis}

The SWOT analysis is an instrument used in strategic planning by looking at the analysis of internal and external conditions. The internal analysis includes an assessment of strength and weakness factor. Meanwhile, the external analysis includes opportunity and challenge (Threats). From the results of SWOT analysis will be known the performance and potential problems that exist in the management of water resources of Depok City area. To conduct a SWOT analysis, focus group discussions, and interviews of interested parties are conducted to determine the current condition of water resources management of Depok City and the future planned policies as well as policies and problems that have not been resolved. From the FGD results, qualitative data are obtained, which in this study will be developed quantitatively through the calculation of SWOT analysis developed by Pearce and Robinso (1998), in order to know the exact position of the real river management. Data on quantitative approaches are categorized as internal and external data. For analysis, usually used External Factor Analysis Summary (EFAS) and Internal Factor Analysis Summary (IFAS). The calculation is done in three stages:

1. Calculate scores (a) and weight (b) factor points and the total number of multiplication scores and weights $(\mathrm{c}=\mathrm{a} \times \mathrm{b})$ on each factor S-W-O-T;

2. Making a reduction between the total number of factors $\mathrm{S}$ with $\mathrm{W}(\mathrm{d})$ and factor $\mathrm{O}$ with $\mathrm{T}$ (e); Acquisition of numbers $(\mathrm{d}=\mathrm{x})$ then becomes a value or point on the $\mathrm{X}$-axis, while the acquisition of numbers $(e=y)$ then becomes a value or point on the $Y$-axis;

3. Finding the position of the problem faced through the position indicated by point $(x, y)$ in the SWOT quadrant.

\section{RESULTS AND DISCUSSION}

\subsection{Indicator Analysis of Water Stress Indicators (WSI) for Depok City Region}

\subsubsection{Water Availability Indicator}

In analyzing water availability, it is necessary to consider the availability of groundwater, surface, and piped water resources. Since the use of groundwater also needs to take into consideration the conditions of environmental carrying capacity and urban development so that 
the use of groundwater needs to be minimized for the future. In addition to groundwater, surface water is also studied more deeply. In this case, the surface water will be affected by the Depok climate in favor of land use with continuous rainfall throughout the year. The following is the measurement result of the fourth river flow in each sub-district.

Table 1 Results of River Debit Measurement per District

\begin{tabular}{|c|c|c|c|c|}
\hline No. & District & River & $\begin{array}{c}\mathrm{Q} \\
\left(\mathrm{m}^{3} / \mathrm{s}\right)\end{array}$ & $\begin{array}{c}\text { Total Debit } \\
\left(\mathrm{m}^{3} / \mathrm{s}\right)\end{array}$ \\
\hline 1 & Cimanggis & Ciliwung & 9.784 & 9.784 \\
\hline 2 & Beji & Ciliwung & 3.209 & 3.209 \\
\hline \multirow{2}{*}{3} & \multirow{2}{*}{ Cinere } & Krukut & 1.619 & \multirow{2}{*}{13.502} \\
\hline & & Pesanggrahan & 11.883 & \\
\hline \multirow{2}{*}{4} & \multirow{2}{*}{ Limo } & Pesanggrahan & 5.943 & \multirow{2}{*}{6.064} \\
\hline & & Ciliwung & 0.121 & \\
\hline \multirow{2}{*}{5} & \multirow{2}{*}{ Sukmajaya } & Ciliwung & 4.300 & \multirow{2}{*}{8.382} \\
\hline & & Ciliwung & 4.082 & \\
\hline 6 & Cilodong & Ciliwung & 7.194 & 7.194 \\
\hline 7 & Pancoran Mas & Pesanggrahan & 0.478 & 0.478 \\
\hline 8 & Cipayung & Pesanggrahan & 0.527 & 0.527 \\
\hline 9 & Sawangan & Ciliwung & 1.459 & 1.459 \\
\hline 10 & Bojongan Sari & Ciliwung & 0.885 & 0.885 \\
\hline 11 & Tapos & Cikeas & 0.985 & 0.985 \\
\hline
\end{tabular}

Table 1 shows that the potential of surface water resources originating from rivers in Depok City is quite enormous. The district with the most significant potential of river water resources is Cinere. Besides the river, other potential surface water that will be studied further in this research is reservoir/lake. The following is a list of the places to be reviewed.

Table 2 Reservoir Location per District

\begin{tabular}{cllcc}
\hline No. & District & \multicolumn{1}{c}{$\begin{array}{c}\text { Presence of Lake } \\
\text { per Sub-District }\end{array}$} & $\begin{array}{c}\text { Debit } \\
\text { per Reservoir } \\
\left(\mathrm{m}^{3} / \mathrm{s}\right)\end{array}$ & $\begin{array}{c}\text { Potential Reservoir } \\
\text { per District } \\
\left(\mathrm{m}^{3} / \mathrm{s}\right)\end{array}$ \\
\hline 1 & Sawangan & Pengasinan Lake & 0.221 & 0.221 \\
\hline 2 & Bojongsari & Sawangan/Bojongsari Lake & 0.453 & 0.453 \\
\hline 3 & Pancoran Mas & Pancoran Mas/Pitara Lake & 0.0145 & 0.0335 \\
\cline { 3 - 4 } & Pulo Asih Lake & 0.019 & 0.1365 \\
\hline 4 & Cipayung & Citayam Lake & 0.1365 & 1.512 \\
\hline 5 & Sukmajaya & Sidomukti Lake & 1.512 & 0.18225 \\
\hline 6 & Cilodong & Bahar Lake & 0.18225 & 0.015 \\
\hline 7 & Cimanggis & Rawakalong Lake & 0.015 & 0.16 \\
\hline 8 & Tapos & Cilangkap Lake & 0.16 & \multirow{2}{*}{0.26305} \\
\hline \multirow{2}{*}{9} & \multirow{2}{*}{ Beji } & Pladen Lake & 0.07315 & \\
\cline { 3 - 4 } & & Mahoni UI Lake & 0.06 & \\
\cline { 3 - 4 } & & Kenanga UI Lake & 0.1299 & \\
\hline
\end{tabular}

Table 2 shows the potential of surface water resources coming from lakes in every district in Depok City. There are some situations that researchers do not get permission to conduct field surveys and also do not get data from the relevant agencies. So that, for the volume of water availability is considered as no potential to be utilized because the object has entered the area of tourism/recreation, the reservoir already transformed into the neighborhood, and some of it has 
changed the function of the land into a garden or already built for community residents. In this study also conducted a study related to the use of piped water network. This is done to know the coverage area of piped network and service quality of PDAM in Depok City. Based on data obtained from the Depok City Tirta Asasta Regional Drinking Water Company, it can be seen that the coverage of piped water services in one city has only reached $\pm 16 \%$, with the most substantial service coverage in the Sukmajaya District, which is $34 \%$. In addition to water availability, an analysis of water consumption based on water accounts (for PDAM customers) and water per person per day for house building is 90 liters/person/day.

Table 3 Calculation of Water Availability Index

\begin{tabular}{clccc}
\hline \multirow{2}{*}{ No. } & \multirow{2}{*}{ District } & $\begin{array}{c}\text { Water Availability } \\
\left(\mathrm{m}^{3} / \text { year.person }\right)\end{array}$ & \multirow{2}{*}{ Score $\mathrm{I}_{1}$} & Total \\
\hline 1 & Sawangan & 390 & 5 & $58,365,244$ \\
\hline 2 & Bojongsari & 379 & 5 & $45,849,100$ \\
\hline 3 & Pancoran Mas & 79 & 5 & $20,160,764$ \\
\hline 4 & Cipayung & 149 & 5 & $23,041,841$ \\
\hline 5 & Sukmajaya & 1,122 & 15 & $315,834,819$ \\
\hline 6 & Cilodong & 1,556 & 15 & $235,705,893$ \\
\hline 7 & Cimanggis & 1,068 & 15 & $313,071,166$ \\
\hline 8 & Tapos & 161 & 5 & $42,087,352$ \\
\hline 9 & Beji & 558 & 10 & $112,197,364$ \\
\hline 10 & Limo & 1,886 & 20 & $194,050,734$ \\
\hline 11 & Cinere & 3,403 & 20 & $427,806,424$ \\
\hline
\end{tabular}

Score assessment is performed on the availability of water discharge per year, where the lowest score is 5 for Sawangan, Bojongsari, Pancoran Mas, Cipayung, and Tapos. The highest score, which is 20 , is given to areas with water availability of more than $1700 \mathrm{~m} 3 /$ year/person for the Limo and Cinere districts.

\subsubsection{Water Continuity Indicator}

Based on the survey results it can be seen that the water drainage of the PDAM network up to now occurs for 6-12 hours, only in Bojongsari, Cipayung, and Cinere sub-districts where pipeline networking lasts less than 6 hours. As for the continuity of other water sources is quite good, which means the flow throughout the year. The calculation of the water continuity indicator score is done on survey data and based on the data obtained by PDAM Tirta Asasta Depok. It can be seen that there is no sub-district in Depok City that reaches score 20, where the highest score is achieved by Sawangan Sub-District which got score 13, which mean long water drainage reaches 12-24 hours. Six sub-districts in Depok City get the lowest score with value eight on the water continuity indicator with the duration of drainage ranging from 6-12 hours per day.

\subsubsection{Water Quality Indicator}

Water quality of piped water in Depok City with physical parameters (odor, taste, and water clarity) is at a pretty good level. For groundwater quality, regarding water quality used by nonPDAM consumer, based on survey results shows that the quality is contaminated lightly. From the analysis of quality of Ciliwung, Pesanggrahan, Cikeas, and Krukut River using STORET method can be seen that the condition of Ciliwung and Pesanggrahan River is heavily polluted while for River/Kali Krukut and Cikeas is contaminated. Thus, for the use of the river as a source of raw water in the future requires further treatment to improve the current quality. Cipayung Sub-District received a score of 10 resulting from a combination of existing river water quality with severe pollutant levels and poor groundwater and piping quality. While 
Tapos District gets the highest score with a value of 15 due to the quality of river water is contaminated while the quality of ground water and piping is quite good.

\subsubsection{Water Consumption Indicator}

The data calculation resulting indicator level of consumption of clean water Depok City are shown in Table 4. Based on the calculation of the indicator of the level of clean water consumption of Depok City, is 61 liters/person/day. The highest water consumption level in Depok City is in Sukmajaya District with the use of clean water per person per day reach 95.01 liters/person/day.

\subsubsection{Land Use Indicator}

The existing land use data of Depok City along with the result of the index score of land use indicator is presented in Figure 1. Based on the data, it can be seen that the Cipayung and Sukmajaya districts have the smallest index score with a value of 12 which means these areas have an impact on the use and contamination of water in the surrounding ecosystem is quite good. While Bojongsari and Beji sub-districts have a score of 16 land use indicators, which means that land use impacts on the districts have a good impact on water use and pollution in the surrounding ecosystem. As already explained, the indicators that have been calculated before will be given different weights. The weighting was conducted based on questionnaires given at the Focus Group Discussion (FGD) to the parties who understood the condition of the water hazard in Depok City. By doing the weighting, it will be known components and indicators that most influence the water-stress conditions based on the opinions of the parties mentioned above.

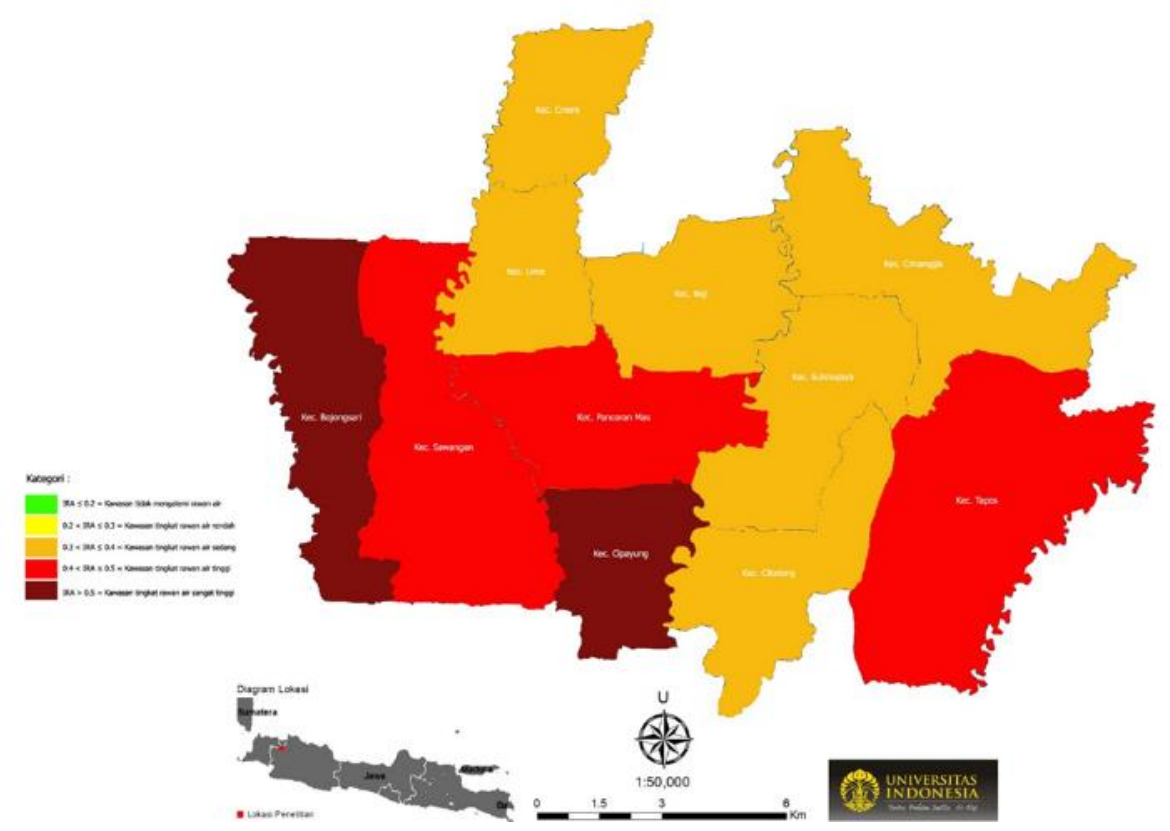

Figure 1 Map of Water Supply Index per District in Depok City

Based on the above calculation it can be seen that in Depok City there are six sub-districts (Sukmajaya, Cilodong, Cimanggis, Beji, Limo, and Cinere) which have moderate water level with WSI value between $0.3-0.4$. While there are three sub-districts (Sawangan, Pancoran Mas, and Tapos) which has a high level of water resistance is the value of WSI between 0.4-0.5. For the district that has the highest water prone value is Bojongsari and Cipayung sub-districts. With WSI value above 0.5 indicates that both sub-districts have very-high water vulnerability, it can be seen from the aspect of piped water that has not served the area so that it affects the value of availability, continuity, and very low water quality. 


\subsection{Water Balance Analysis for Depok Area}

Water balance is based on PDAM piped water usage and PDAM Tirta Asasta water supply developments plan. Also, the increase of PDAM Tirta Asasta production capacity is adjusted to its target with PDAM Tirta Asasta. From Table 4, until the year 2017, Depok city experiencing depletion or lack of water supply from PDAM Tirta Asasta. But, this has been anticipated with the increase of production capacity of PDAM equal to 2,286 liters/s and addition of supply from clean water treatment plant (IPA) in Legong, Citayam, Duren Seribu, and Cinere areas so that the total production capacity of PDAM Tirta Asasta in 2,022 reaches 3,475 liter/s. However, the addition of supply is only sufficient for the clean water needs of the city of Depok which continues to increase until 2027. Therefore, the increase of clean water production capacity in 2027 is needed again to meet the clean water needs of Depok city.

Table 4 Water Balance of Depok City

\begin{tabular}{|c|c|c|c|c|c|}
\hline \multirow{2}{*}{ No. } & \multirow{2}{*}{ Design Parameter } & \multirow{2}{*}{ Unit } & \multicolumn{3}{|c|}{ Year } \\
\hline & & & 2017 & 2022 & 2027 \\
\hline 1 & Total population & Person & $2,106,102$ & $2,180,447$ & $2,257,417$ \\
\hline 2 & $\begin{array}{l}\text { Target coverage of clean water } \\
\text { service/drinking piping }\end{array}$ & $\%$ & 65 & 84.15 & 100 \\
\hline 3 & Maximum limits of ground & $\%$ & 20 & 15 & 0 \\
\hline 4 & Total population served & Person & $1,368,966$ & $1,834,846$ & $2,257,417$ \\
\hline 5 & Domestic clean water consumption & L/person/day & 61.43 & 75 & 80 \\
\hline 6 & Domestic clean water needs & $\mathrm{L} / \mathrm{s}$ & 973 & 1,593 & 2,090 \\
\hline 7 & Non-domestic needs & $\mathrm{L} / \mathrm{s}$ & 321 & 526 & 690 \\
\hline 8 & Non-revenue water (NRW) & $\%$ & 31.87 & 25 & 20 \\
\hline 9 & Total clean water needs & $\mathrm{L} / \mathrm{s}$ & 1,707 & 2,648 & 3,336 \\
\hline 10 & Total raw water requirement & $\mathrm{L} / \mathrm{s}$ & 1,792 & 2,780 & 3,503 \\
\hline \multirow{5}{*}{11} & $\begin{array}{l}\text { Total production capacity of PDAM } \\
\text { Tirta Asasta }\end{array}$ & \multirow{5}{*}{$\mathrm{L} / \mathrm{s}$} & 1,095 & 2,285 & 2,285 \\
\hline & Supply of IPA Legong & & 0 & 670 & 670 \\
\hline & Supply of IPA Citayam & & 0 & 120 & 120 \\
\hline & Supply of IPA Duren Seribu (Angke) & & 0 & 100 & 100 \\
\hline & Supply of IPA Cinere/Pesanggrahan & & 0 & 300 & 300 \\
\hline 12 & Water deficit (raw \& clean water) & $\mathrm{L} / \mathrm{s}$ & -697.45 & -694.66 & -27.76 \\
\hline
\end{tabular}

\subsection{SWOT Analysis}

Based on the results of the analysis on the calculation of weights and scores for the parameters in the SWOT analysis, it is found that the management of water resources of Depok City is currently in an unfavorable condition, namely quadrant IV (with coordinates -2.68, -0.29). This position signifies a weak condition and faces a big challenge. Thus, based on literature references, the WT strategy is to be applied, i.e., Adaptive Strategy, which reduces the weaknesses and avoid threats. Therefore, the management of water resources Depok City is recommended to control the internal performance from falling apart. This strategy is maintained while continuing to improve itself. 
Table 5 Matrix of Water Resources Management Strategy

\begin{tabular}{ll}
\hline \multicolumn{1}{c}{$\begin{array}{c}\text { Recommendations for management of water resources in Depok City } \\
\text { based on SWOT analysis }\end{array}$} \\
\hline \multicolumn{1}{c}{\begin{tabular}{c}
\multicolumn{1}{c}{ Internal: } \\
$\begin{array}{l}\text { Addition and improvement of water } \\
\text { storage infrastructure also the number of } \\
\text { water connections piped water }\end{array}$
\end{tabular}} & $\begin{array}{l}\text { Law enforcement against people using } \\
\text { excessive groundwater }\end{array}$ \\
\hline $\begin{array}{l}\text { Increase awareness, coordination, and } \\
\text { commitment on all elements of } \\
\text { government, society, and stakeholders }\end{array}$ & $\begin{array}{l}\text { Conduct a green environmental } \\
\text { campaign }\end{array}$ \\
\hline $\begin{array}{ll}\text { Improving the quality of human resources } \\
\text { Conducting studies or enrichment of }\end{array}$ & $\begin{array}{l}\text { City community for environmental } \\
\text { management }\end{array}$ \\
\hline $\begin{array}{l}\text { Coneparing and improving disaster } \\
\text { science, i.e. shallow groundwater policies } \\
\text { mitigation for Depok City }\end{array}$ \\
\hline
\end{tabular}

\section{CONCLUSION}

Through this research, it can be seen that Depok City has the potential for water resources that have not been used optimally. Through the WSI analysis, it can be seen that several subdistricts in Depok are experiencing very high water-prone conditions, namely Bojongsari and Cipayung. Conditions of lakes and rivers that are not by the designation cause the need for special treatment to be used as a source of raw water. This needs to be done to avoid the raw water deficit in 2027, by the calculation of the water balance that has been carried out. From the SWOT analysis of water resources management, it can be seen that there is a need for an increase in the internal performance of all authorized parties both regarding expertise and technical aspect. Also, there is a need to increase public awareness through environmental campaign programs or a special social approach on the smallest scale of the community unit (Rukun Tetangga). Thus, this research is expected to be used as a direction in formulating policies and as an early warning for readers in facing the water crisis that continues to occur today.

\section{ACKNOWLEDGEMENT}

We thank our colleagues who provided insight and expertise that greatly assisted the research, the colleagues are among others: Experts and Academics related to Water Resources Management; Regional Development Planning Agency (BAPPEDA) Depok City; Department of Environment and Cleanliness of Depok City; Department of Public Works and Spatial Planning of Depok City; Representatives from 11 sub-districts in Depok City; Water Supply Forum of Depok City.

\section{REFERENCES}

Ali, F., 2011. Kajian Strategis dan Perencanaan Strategi Tingkat Ketahanan Air (Water Security) Prov. DKI Jakarta Menuju 2030.

Molle, F., Mollinga, P., 2003. Water poverty indicators: conceptual problems and policy issues. Water Policy, 5:529-544.

Lestari, D.L., 2011. Mapping of Clean Water Prone Areas in East Jakarta and Central Jakarta Areas Based on Water Stress Index. Universitas Indonesia. 
Mlote, S.D.M., Sullivan, C., Meigh, J., 2002. Water Poverty Index: a Tool for Integrated Water Management. Paper presented at 3rd WaterNet/Warfsa Symposium 'Water Demand Management for Sustainable Development', Dar es Salaam.

Sullivan, C., Meigh, J., Lawrence, P. 2005. Application of the Water Poverty Index at Different Scales: A Cautionary Tale. Agriculture Ecosystems and the Environment.

Sullivan, C. A., Meigh, J. R., Giacomello, A. M., 2003. The Water Poverty Index: Development and Application at the Community Scale. Natural Resources, 27: 189 - 199. 